\title{
Вплив технічних та географічних параметрів на дальність знімання мовної інформації при вирішенні прикладних
}

\section{завдань}

\author{
Олена Азаренко * 1 А Юлія Гончаренко 2 в; Михайло Дівізінюк ${ }^{3}$ с; \\ Володимир Мірненко ${ }^{4}$; ; Валерій Стрілець ${ }^{5 \text { A }}$ \\ А Науково-дослідний лабораторно-експериментальний центр “БРАНД ТРЕЙД”, м. Київ, Україна

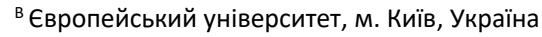 \\ с Інститут геохімії та навколишнього середовища НАН України, м. Київ, Україна \\ ' Департамент військової освіти та науки Міністерства оборони України, м. Київ, Україна
}

Received: November 25, 2021 | Revised: December 10, 2021 | Accepted: December 30, 2021

DOI: $10.33445 /$ sds.2021.11.6.2

\begin{abstract}
Анотація
Ця стаптя присвячена розгляду основних технічних параметрів акустичних засобів та географічних факторів місцевості на дальність знімання мовної інформації при вирішенні прикладних завдань захисту об'єктів критичної інфраструктури від терористичних актів. Спочатку дано характеристика основних технічних параметрів акустичних засобів знімання мовної інформації. Показано, що Основними технічними параметрами акустичних засобів знімання мовної інформації є чутливість мікрофона, його спрямованість, робоча смуга частот і коефіцієнт розпізнавання. Потім розглянути поняття енергетичної дальності виявлення акустичних сигналів. Показано, що під енергетичною дальністю дії акустичного засобу розуміється найбільше розрахункове значення дистанції, що забезпечує рівність енергетичного потенціалу акустичного засобу та закономірності спаду інтенсивності розповсюджується акустичної хвилі. Після чого проаналізовано геометрична дальність виявлення акустичних сигналів, з урахуванням рельєфу місцевості навколо об'єкту критичної інфраструктури. Показано, що геометрична дальність виявлення акустичних сигналів буде визначатися геометричній дальністю видимого горизонту з урахуванням позитивного і негативного рельєфу місцевості, наявністю житлових масивів, лісів та водойм, а також станом підстилаючої поверхні навколо об'єкту критичної інфраструктури в напрямку, який визначається розворотом акустичного пристрою. Потім розглянуто очікувана дальність знімання мовної інформації, як результат співвідношення енергетичної і геометричній діяльностей виявлення акустичних сигналів. Показано, що очікувана дальність знімання мовної інформації визначається як добуток енергетичної дальності виявлення акустичних сигналів на значення коефіцієнта впливу середовища в приземних шарах атмосфери. Якщо отриманий результат перевищує значення геометричної дальності виявлення акустичного сигналу, то за значення очікуваної дальності приймається геометрична дальність виявлення.
\end{abstract}

Ключові слова: терористичний акт, захист, акустичний контроль, мікрофон, дальність.

\section{Постановка проблеми}

Під критичною інфраструктурою прийнято розуміти сукупність підприємств, мереж, систем, вихід із ладу яких може спричинити втрату управління або завдати істотних збитків на загальнодержавному, регіональному, місцевому чи об'єктовому

\footnotetext{
1 * Corresponding author: д.ф.-м.н., професор, заступник керівника, e-mail: azarenko_ev@ukr.net, ORCID: 0000-0003-2927-5545

2 к.т.н., доцент, професор кафедри, e-mail: vup@e-u.in.ua, ORCID: 0000-0003-2045-0263

3 д.ф-м., професор, головний науковий співробітник, e-mail: divizinyuk@ukr.net, ORCID: 0000-0002-5657-2302

${ }^{4}$ д.т.н., професор, Заслужений працівник освіти України, директор, e-mail: mirnenkovi@gmail.com, ORCID: 0000-0002-7484-1035

${ }^{5}$ керівник, e-mail: v.strelec.brand@gmail.com, ORCID: 0000-0003-1913-7878
} 
рівні [1]. До їі складу входять атомні та гідроелектростанції, хімічні та нафтохімічні комбінати, металургійні заводи та інші державні підприємства та приватні установи стратегічного призначення. Для забезпечення безпеки цих підприємств та запобігання надзвичайним ситуаціям терористичного характеру (HC TX) у їхніх структурах $€$ спеціальні підрозділи охорони або фізичного захисту [2-4]. Цими підрозділами використовуються інженернотехнічні загородження та фізичні бар'єри, засоби оптоелектронного та інфрачервоного спостереження, радіолокаційного та акустичного контролю [5-7]. Засоби акустичного контролю це технічні прилади, що забезпечують знімання акустичної та мовної інформації на відкритій місцевості. Ці спеціальні електронні прилади називаються спрямованими мікрофонами. В даний час їх поділяють на чотири види: параболічні, плоскі акустичні, фазовані решітки, трубчасті (мікрофони біжучої хвилі) і градієнтні. $[8,9]$, дальність дії яких може досягати декількох кілометрів $[10,11]$. Однак дальність знімання мовної інформації на відкритій місцевості залежить від стану приземних шарів атмосфери та гідрометеорологічних явищ, технічних параметрів спрямованих мікрофонів та географічних факторів [12-14]. Останні зумовлені характером рельєфу місцевості в районі знаходження об'єкта критичної інфраструктури та на підходах до нього, рослинністю на земній поверхні, наявністю лісів та водойм, будівельних споруд різного призначення.

Головне завдання систем фізичного захисту об'єктів критичної інфраструктури це недопущення терористичних актів на об'єктах, що охороняється [3, 15]. Ефективність вирішення цього завдання залежить від своєчасного виявлення зловмисників, що визначається дальністю дії засобів виявлення та контролю.

\section{Постановка завдання}

Тому метою даної роботи $\epsilon$ розгляд основних технічних параметрів акустичних засобів та географічних факторів місцевості на дальність знімання мовної інформації при вирішенні прикладних завдань захисту об'єктів критичної інфраструктури від терористичних актів.

Для досягнення поставленої мети необхідно вирішити наступні наукові завдання.

Спочатку дати характеристику основних технічних параметрів акустичних засобів знімання мовної інформації. Потім розглянути поняття енергетичної дальності виявлення акустичних сигналів. Після чого проаналізувати геометричну дальність виявлення акустичних сигналів, 3 урахуванням рельєфу місцевості навколо об'єкту критичної інфраструктури. Потім розглянути очікувану дальність знімання мовної інформації, як результат співвідношення енергетичної і геометричній діяльностей виявлення акустичних сигналів.

\section{Виклад основного матеріалу}

\section{Характеристика основних технічних параметрів акустичних засобів знімання мовної інформації}

Для знімання інформації на відкритих майданчиках, як було зазначено раніше, використовуються різні типи спрямованих мікрофонів. Це можуть бути такі типи: параболічний, фазирована акустична решітка, трубчастий, градієнтний. Всі вони мають такі технічні характеристики. Це чутливість, ширина характеристики спрямованості, коефіцієнт осьової концентрації, коефіцієнт розпізнавання, роздільна здатність по кутових координатах, робоча смуга частот, центральна частота, рівень власних шумів.

Чутливість мікрофона $E$ - це відношення знімається з мікрофона електричного сигналу 
до акустичного тиску звукової хвилі, що впливає на нього. Вимірюється мВ·Па ${ }^{-1}$ i залежить від частоти. Функціональна залежність зміни чутливості мікрофона від

$E$,

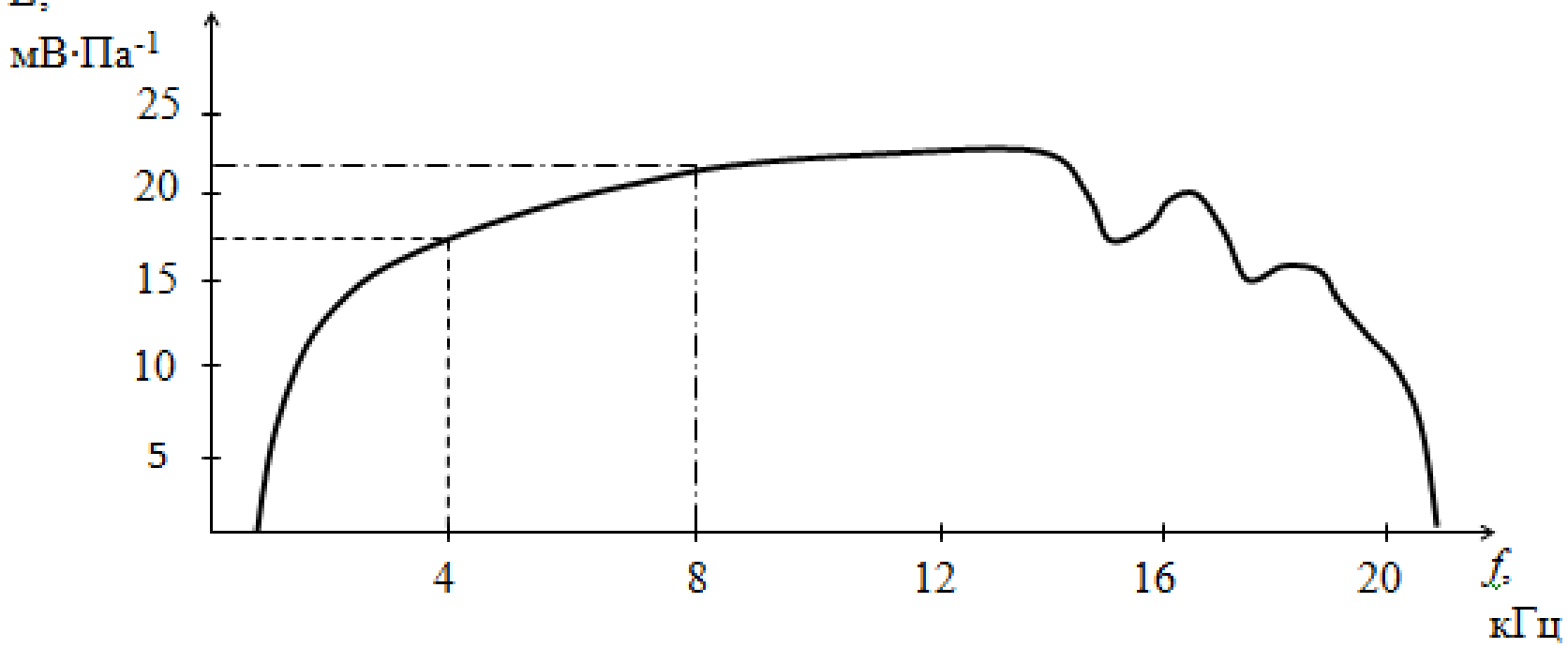

частоти $\epsilon$ його амплітудно-частотної характеристикою, приклад якої наведено на рис. 1.

Рисунок 1 - Амплітудно-частотна характеристика мікрофона

3 цієї причини для різних частот значення чутливості мікрофона будуть різними. У той же час на фіксованій частоті просторова чутливість мікрофона буде змінюватися. Приклад цієї залежності в горизонтальній площині представлений на рис. 2. її називають характеристикою спрямованості мікрофона в горизонтальній площині. Відповідна залежність $€$ і у вертикальній площині, яку називають характеристикою спрямованості мікрофона у вертикальній площині.

До складу характеристики спрямованості входять основний (головний) і другорядні (паразитні) максимуми. Величина кута, що визначає значення на рівні 0,707 головного максимуму, $\epsilon$ шириною характеристики спрямованості $\left(\Theta_{\mathrm{xH}}\right)$.

Відношення величини реєстрованого сигналу від джерела звуку, що знаходиться на осі головного максимуму спрямованого мікрофона, до величини сигналу від цього ж джерела, що знаходиться на цьому ж відстані при ненаправленим прийомі, прийнято називати коефіцієнтом спрямованої дії $j_{\text {пр }}$.

Мінімальний кут, при якому дві акустичні (шумливі) ціли, можна розв'язати (спостерігаються роздільно) при направленому прийомі називають роздільною здатністю мікрофона по куту $\Delta \Theta$.

Робоча смуга частот $\Delta F$ визначається різницею верхньої і нижньої частот, що використовуються в робочій амплітудночастотній характеристиці мікрофона $\left(f_{\mathrm{B}}-f_{\mathrm{H}}\right)$, а центральна частота $f_{0}$ визначається, як середнє геометрична величина, тобто $f_{0}=$ $\sqrt{f_{\mathrm{B}} \cdot f_{\mathrm{H}}}$.

Коефіцієнт розпізнавання $\delta$ - це мінімальне співвідношення величини корисного сигналу до величини перешкоди, яке достовірно реєструється на приймальний пристрій при заданих значеннях ймовірності правильного виявлення і ймовірності помилкової тривоги. Для розрахунку цієї величини використовуються значення чутливості мікрофона в робочій смузі частот. 


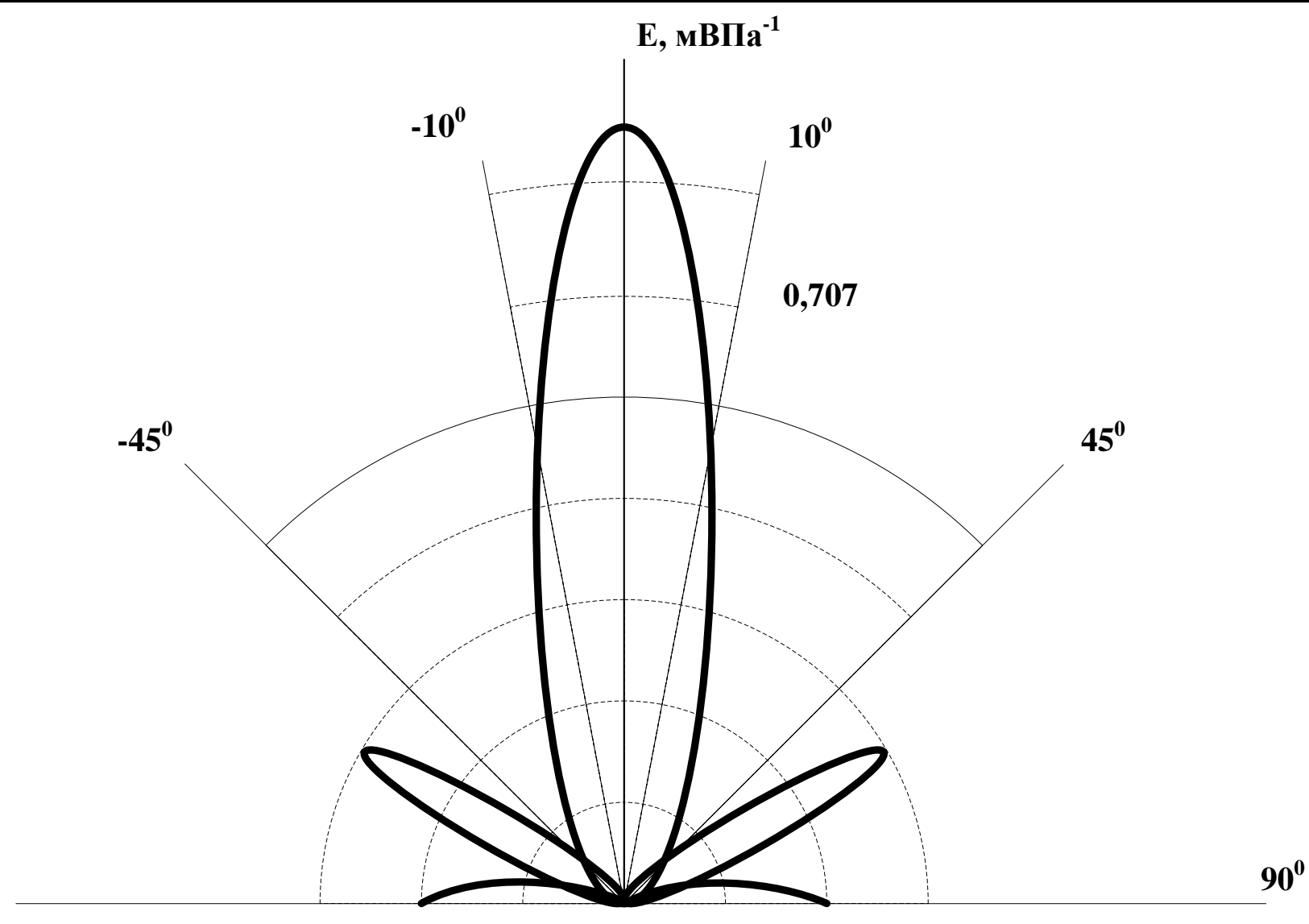

Рисунок 2 - Характеристика спрямованості мікрофона

(в горизонтальній площині)

Рівень власних шумів мікрофона $\mathrm{P}_{\text {Пс }} \epsilon$ паспортної технічною характеристикою, що залежить від використовуваних матеріалів, якості виготовлення і інших чинників, як правило, незмінна величина для одних і тих же термобарических умов.

Параметри акустичної ціли визначаються головним чином інтенсивністю шуму і його спектром.

Формалізуючи цей процес, акустиками було прийнято говорити про наведену шумність, тобто значенням акустичного тиску створюваного джерела на відстані одного метра на частоті 1 кГц в смузі 1 Гц. Однак приймальні пристрої фіксують сигнали в робочій смузі частот $\Delta F$, яка визначається верхньої і нижньої частотами. 3 цих причин, аналізуючи технічні засоби, акустики говорять про наведену шумності, як про значення акустичного тиску, створюваного джерелом на відстані одного метра в робочій смузі частот приймального пристрою. При цьому використовують термін не робоча смуга частот, а гучність на центральній частоті. Спектральні характеристики акустичних цілей, до яких відносяться ширина спектра, параметри його спаду, дискретні складові, тимчасові варіації, амплітудно-частотні та тональні особливості, деталізувати не будемо. Відзначимо лише те, що вони $є$ головним фактором, що дозволяє їх ідентифікувати (класифікувати і впізнати, тобто прив'язати індивідуально).

Таким чином, основними технічними параметрами акустичних засобів знімання мовної інформації є чутливість мікрофона, його спрямованість, робоча смуга частот i коефіцієнт розпізнавання.

Енергетична дальність виявлення акустичних сигналів

Головна умова реєстрації акустичних хвиль на приймальний пристрій це виконання 
співвідношення в якому інтенсивність корисного сигналу в $\delta$ разів перевищує інтенсивність перешкоди, що впливає на вхід цього ж приймача [8-14], тобто

$$
I_{c} \geq \delta I_{n} \quad \text { але } \quad P_{c}^{2} \geq \delta P_{n} .
$$

де $\delta$ - коефіцієнт розпізнавання акустичного приймального пристрою.

$P_{c}$ и $P_{n}-$ значення акустичного тиску, що створюється корисним сигналом (розмовною мовою) і перешкодою.

Акустичні хвилі в атмосфері поширюються по циліндричному і сферичному законам, який визначається двома факторами, а саме геометричними розмірами джерел звуку i відстанями, на які звуки поширюються. Якщо ці параметри спів мірні, то працює циліндричний закон. Якщо відстань, на яке поширюється звук набагато більше, ніж розміри його джерела, то джерело звуку вважається точковим, а поширення хвиль відбувається по сферичному закону. У першому випадку фронт хвилі розширюється як стінки циліндра, i інтенсивність звуку зменшується пропорційно відстані. У другому випадку фронт хвилі розширюється як поверхня сфери, і інтенсивність звуку зменшується пропорційно квадрату відстані. У нашому випадку, випадку знімання мовної інформації, працює сферичний закон. Крім цього, внаслідок релаксаційних процесів, що відбуваються в атмосфері, відбувається загасання звуку на величину $\alpha$, конкретне значення якої залежить від частоти акустичних хвиль і деяких фізичних параметрів приземних шарів атмосфери.

Інтенсивність поширюється акустичного сигналу може бути збільшена на величину $j_{u}$, яка визначається спрямованим дією джерела, наприклад, людина розмовляє біля стіни (будівлі). Тут звук буде поширюватися в півсфері і коефіцієнт концентрації джерела звуку $j_{u}$ буде дорівнює двом. Якщо ж розмова відбуватиметься у двох стін, розміщених ортогональне (під кутом 90 градусів) один до одного, то поширення звуку буде відбуватися в чверть сфери і, відповідно значення $j_{u}$ буде дорівнює чотирьом. Аналогічним чином буде зменшено вплив перешкоди за рахунок спрямованих дій мікрофона, яке буде визначатися коефіцієнтом його концентрації $j_{n p}$. 3 урахуванням усього вищевикладеного, вираз (2) набуде вигляду:

$$
\frac{P_{c}^{2} j_{u}}{4 \pi Д^{2}} \cdot 10^{-0,1 \alpha Д} \geq \delta \frac{P_{n}^{2}}{j_{n p}} .
$$

Виконавши логарифмування і множення на 10 обох частин висловлювання (переведення в децибельну форму) отримаємо наступне

$$
-\left(20 \lg \left(\frac{Д}{A_{0}}\right)+\alpha Д+10 \lg 4 \pi\right) \geq \geq 10 \lg \delta+20 \lg \left(\frac{P_{n}}{P_{0}}\right)-20 \lg \left(\frac{P_{c}}{P_{0}}\right)-10 \lg j_{u}-10 \lg j_{n p} .
$$

де До - нульовий рівень дистанції рівний одному метру,

$P_{0}-$ поріг чутності людського вуха, рівний 2 . $10^{-5}$ Па.

Оскільки ці значення є стандартними для акустики їх в наступних записах вживати не будемо.

Ліва частина виразу $20 \mathrm{lg}$ Д $+\alpha Д+$ $10 \lg 4 \pi$ являє собою закономірність спаду акустичного поля в стандартній (однорідної і безмежної) атмосфері. Права частина вираження (3) прийнято називати енергетичним потенціалом приймального пристрою (з коефіцієнтом спрямованої дії акустичної системи j) по певної цілі (з наведеним значенням шумності до смуги приймального пристрою $\left.P_{c}\right)$ в конкретній помеховой обстановці (рівнем місцевого акустичного фону в смузі приймального пристрою $P_{\text {п) }}[11,14]$.

Найбільше значення дистанції Д, при якому досягається рівність обох частин, $є$ найбільшою або енергетичної дальністю виявлення акустичного сигналу.

Строго кажучи, жоден 3 розглянутих параметрів, жодна з вимірюваних величин не $\epsilon$ постійною. Вони всі мають складні функціональні залежності, врахувати які для поточного стану часу неможливо. 3 цих причин в літературних джерелах пропонуються 
ідеальні умови вирішення завдань. Робляться припущення, що на даний період часу всі параметри, що визначають стан фізичної системи постійні і беруться тільки два, один 3 яких $\epsilon$ аргументом, а інший - відповідна функція. Фактор середовища в цьому випадку не враховується. Середовище вважається безмежної і однорідною, в якій загасання звуку відбувається на величину $\alpha$, значення якої визначається центральною частотою приймального пристрою.

Сукупність технічних факторів приймального пристрою вважатимемо постійними величинами. Перешкоди, які визначаються власними шумами, також вважатимемо постійними. Значення рівня шумів в смузі прийому для кожної акустичної мети індивідуально. Відповідно, чим вище рівень шумів, тим більше дальність виявлення. Крім цього так само говорять, що об'єднання технічних параметрів приймального пристрою і акустичних параметрів джерела звуку $\epsilon$ енергетичний потенціал виявлення певного пристрою за конкретною акустичної мети. Вираз (3) прийнято називати нестрогим нерівністю дальності дії акустичного засоби виявлення. Запишемо його в такий спосіб

$$
20 \cdot \lg Д+\alpha Д_{\text {км }}+K \leq\left(10 \cdot \lg \delta+20 \cdot \lg P_{\text {п }}-10 \cdot \lg J_{\text {пр }}-20 \cdot \lg \mathrm{P}_{\mathrm{c}}\right) \text {, }
$$

де $10 \lg 4 \pi=K \approx 10,98$ дБ.

$\delta$ - коефіцієнт розпізнавання приймального пристрою

$J_{\text {пр }} \quad$ коефіцієнт спрямованої дії спрямованого мікрофона

$\mathrm{P}_{\mathrm{C}}$ - інтенсивність акустичного випромінювання мети в смузі частот приймального акустичного пристрою

Цю частину нерівності прийнято також називати енергетичним потенціалом приймального акустичного пристрою по певної мети (джерела звуку), яка позначається як ПєАц.

Ліву частину виразу (4) - закономірність спаду інтенсивності розповсюджується акустичної хвилі, позначимо як $(Д, f)$, де $f_{0}$ - центральна частота приймального акустичного пристрою. Тепер вираз (4) набуде вигляду:

$$
\Psi\left(Д, f_{0}\right) \leq \Pi_{\in А Ц} \cdot
$$

Таким чином, під енергетичною дальністю дії акустичного засобу розуміється найбільше розрахункове значення дистанції, що забезпечує рівність енергетичного потенціалу акустичного засобу та закономірності спаду інтенсивності розповсюджується акустичної хвилі.

Геометрична дальність виявлення акустичних сигналів, з урахуванням рельєфу місцевості навколо об'єкту критичної інфраструктури

Енергетична дальність виявлення ДЕ $€$ розрахунковою величиною і не враховує конфігурацію Землі, особливості рельєфу місцевості в районі об'єкту критичної інфраструктури. Це враховує геометрична дальність.

Дальність акустичного контролю заснована на принципі прямолінійного поширення акустичних променів, як світла. Викривлення земної поверхні внаслідок того, що Земля має кулясту форму, викликає формування зон освітленості і зон тіні, як показано на рис.3.

Цілі, що знаходяться в зоні тіні, не виявляються. Поділ приземного простору на зону освітленості і зону тіні проходить по площині (лінії) горизонту. 


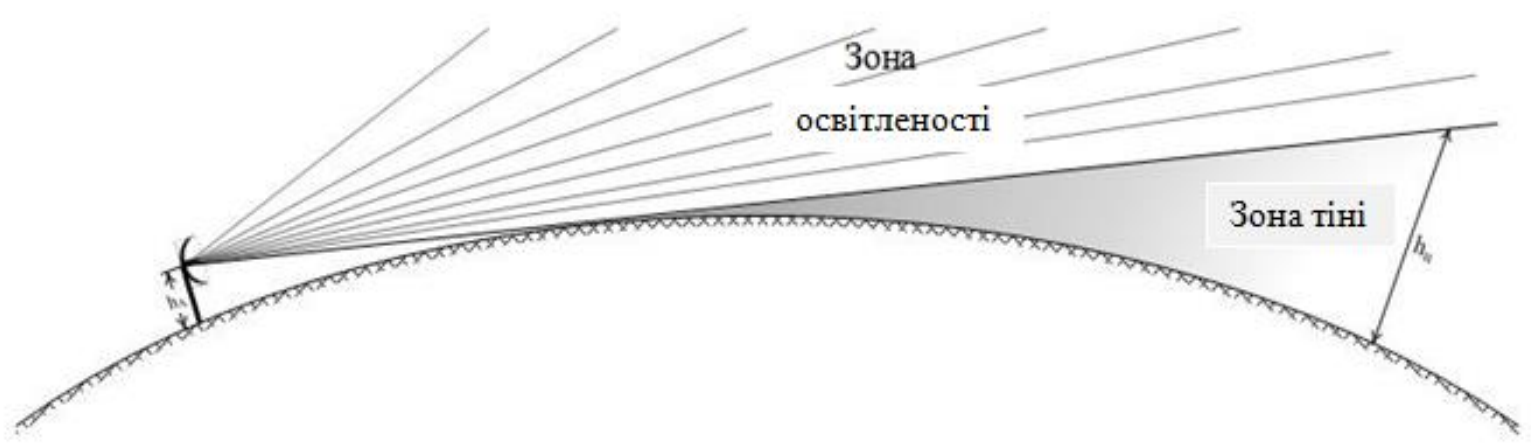

Рисунок 3 - Схема формування зон освітленості та тіні за рахунок скривлення земної поверхні

Проходження цієї лінії обумовлено висотою розташування акустичного пристрою $h_{A}$ і висотою цілі $h_{4}$. Чим вище ці висоти, тим більше дальність видимого горизонту Двг. Вона обчислюється за емпіричною формулою

$$
Д_{\mathrm{B \Gamma}}=4,12 \cdot\left(\sqrt{h_{A}}+\sqrt{h_{ц}}\right)
$$

в якій результат - дальність видимого горизонту, виходить в км, а вихідні довжини антени і цілі в метрах.

Рельєф - це сукупність нерівностей земної поверхні. Вони можуть бути позитивними або вигнутими - гори, пагорби, височини. Вони можуть бути негативними або увігнутими яри, каньйони, ущелини. Ці нерівності не можуть не впливати на поширення звуку в приземних шарах атмосфери. Очевидними фактами $\epsilon$ те, що чим вище розташовується джерело звуку, тим на більшу дальність поширюються акустичні хвилі і навпаки. У разі негативного рельєфу, чим глибше (нижче) розташовується джерело звуку, тим на меншу дальність поширюються акустичні хвилі. Приклад формування зон акустичної освітленості і зон акустичної тіні представлений на рис. 4.

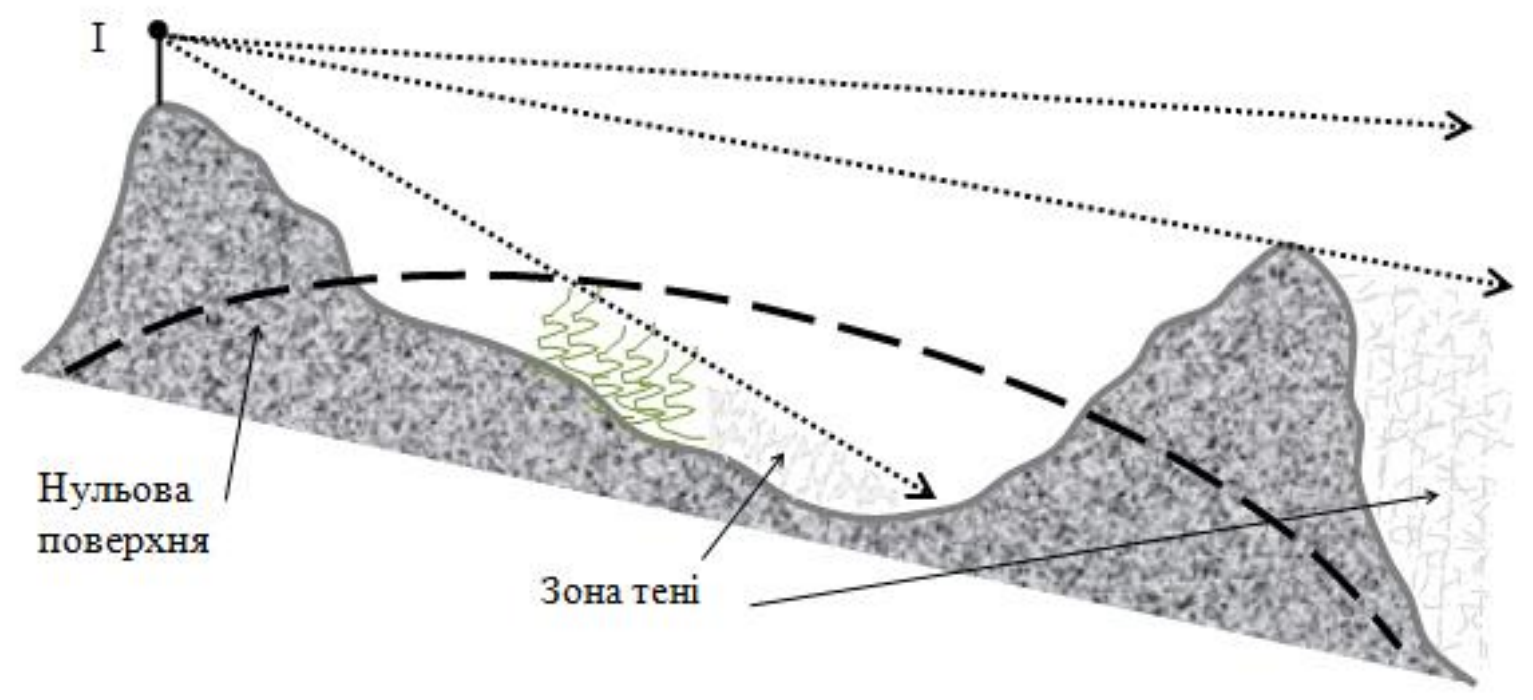

Рисунок 4 - Схема формування зон освітленості і зон тіні

За рахунок височин і лісового масиву утворюються зони тіні. Зона освітленості тут визначається геометричній видимістю. Необхідно так само відзначити, що ліс, 
лісопаркова зона, зарості, чагарники $\epsilon$ відбувається каналізація акустичної енергії, природними звуковими бар'єрами тому звук поширюється на набагато більшу (екранами) так само, як гори, пагорби і відстань, ніж в районах 3 рівнинною височини. 3 іншого боку, коли звукова хвиля поверхнею (плоским рельєфом). Стан i поширюється вздовж ущелин, уздовж заплав характер підстильної поверхні впливає на річок, обрамлених крутими берегами, поширення звуку, як показано на рис. 5.

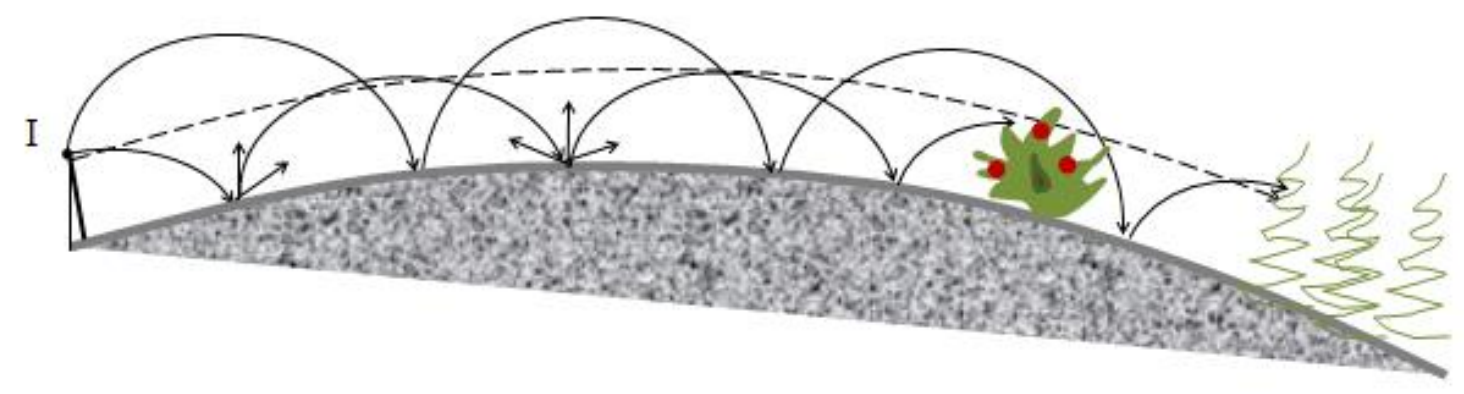

Рисунок 5 - Схема впливу підстильної поверхні.

Наддалеке поширення звуку при позитивній рефракції акустичних променів на увазі не тільки огинання земної поверхні і багаторазове відбиття від неї. У разі, якщо це щільний ґрунт, скеляста поверхню або дзеркальна (спокійна) водна поверхня, то акустичні промені відбиваються від неї і поширюються далі.

Співвідношення відбитої акустичної енергії по відношенню до падаючої становить 70-80\% і більше. Безумовно, якщо на шляху акустичних променів, що забезпечують наддалеке поширення звуку, буде чагарник або лісосмуга, то тут відбудеться повне розсіювання акустичної енергії і ніякого відображення i подальшого поширення не буде.

Особливістю підстильної поверхні може бути й інший фактор - молода рослинна поросль - трава висотою від 10 до $40 \mathrm{~cm}$ і більше. В цьому випадку енергетичні втрати дуже великі і величина відбитого від земної поверхні акустичного сигналу ледь досягає 715\% значень інтенсивності падаючої хвилі.

Відображення від піщаної поверхні приблизно в 1,5-2 рази більше, але це в тому випадку, якщо вона знаходиться в стані повного спокою - без руху. Якщо в цей час під піщаної поверхнею вітер перейде, зриваючи верхню кромку піску, то кількість відбитої акустичної енергії різко зменшується. Аналогічна ситуація відбувається з водною поверхнею. З'являється на поверхні води водойм брижі в 2-2,5 рази зменшує величину відображеної акустичної енергії, що виникає після цього хвилювання водної поверхні висотою 30-50 см і більше, призводить до повного поглинання падаючої звукової хвилі.

У той же час наявність твердого покриття на рівнинній земної поверхні, наприклад, асфальтової автомобільної дороги, залізобетонної злітно-посадкової смуги, утрамбованої майданчики для стоянки автотранспорту тощо, сприяють відображенню звукових хвиль і їх подальшому поширенню.

Так само необхідно відзначити, що асфальтове покриття і перпендикулярний планування і забудова житлових кварталів має подвійний вплив на поширення звукових хвиль. 3 одного боку, коли джерело звуку знаходиться на певній відстані від будівель, то житловий квартал виступає як звукопоглинальне захисна споруда i перешкоджає наддалекої поширенню звуку, як показано на рис. 6. 


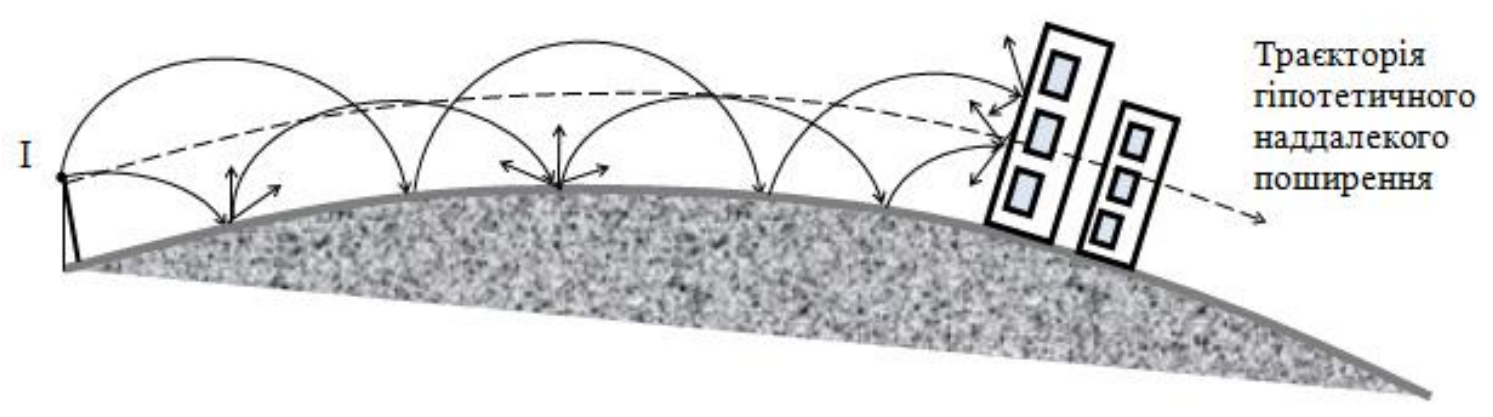

Рисунок 6 - Схема перешкоди наддалеке поширення звуку житловим масивом

3 іншого, коли джерело звуку акустичної енергії і сприяють ії наддалекої знаходиться в житловому масиві (рис. 7), то поширенню, подібно поширенню звуку в житлові квартали, які стоять по обидва боки і довгому порожньому прямокутному асфальтове покриття 3 третьої боку коридорі. створюють сприятливі умови для каналізації

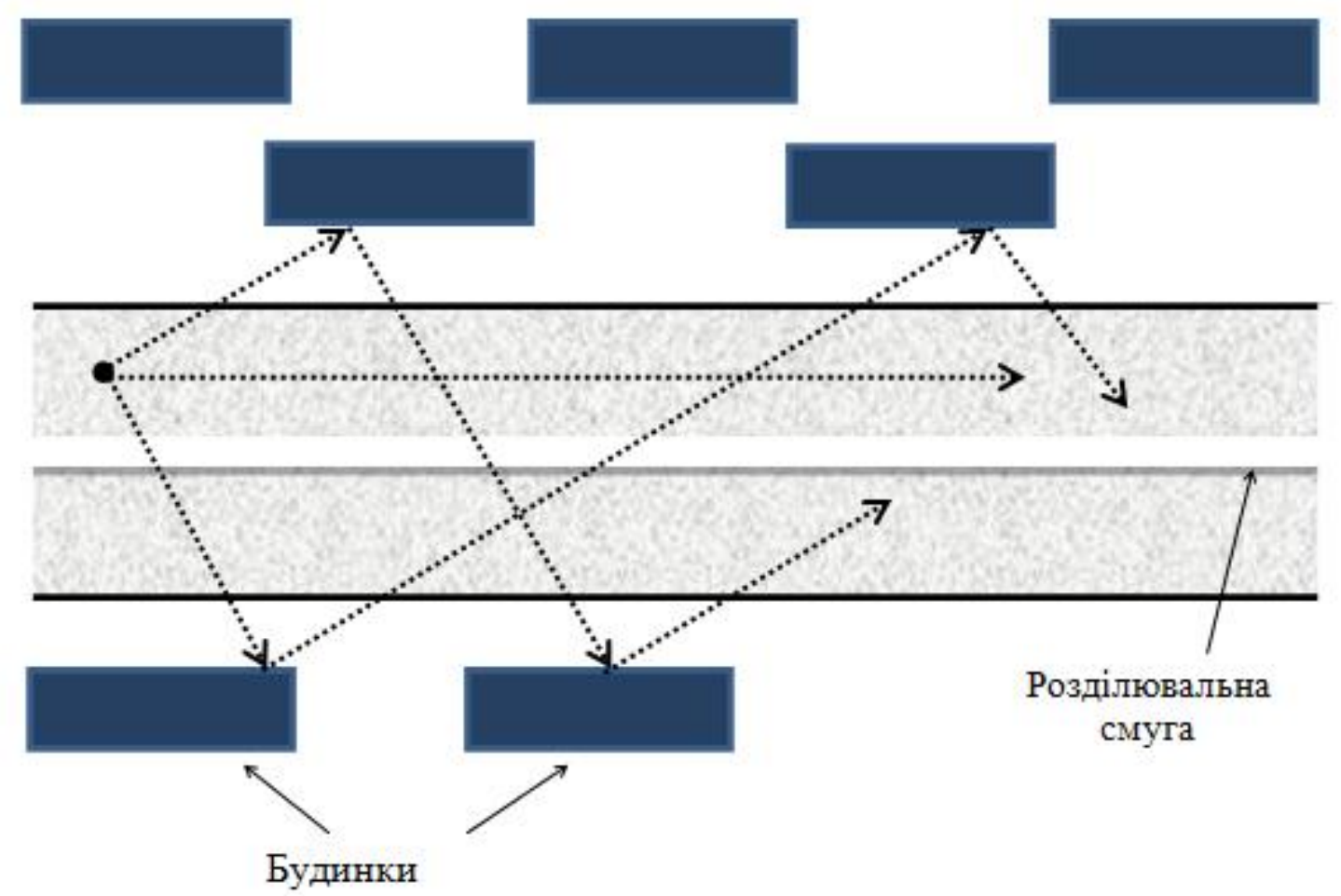

Рисунок 7 - Схема каналізації акустичної енергії в житловому масиві

Іншими словами, нерівність рельєфу з одного боку, наявність рослинності і стан підстильної поверхні з іншого боку можуть сприяти або перешкоджати наддалекої поширенню звуку, що визначається сприятливим вертикальним розподілом швидкості поширення звуку.
Таким чином, геометрична дальність виявлення акустичних сигналів буде визначатися геометричній дальністю видимого горизонту 3 урахуванням позитивного і негативного рельєфу місцевості, наявністю житлових масивів, лісів та водойм, а також станом підстилаючої 
поверхні навколо об'єкту критичної інфраструктури В напрямку, який визначається розворотом акустичного пристрою.

Очікувана дальність знімання мовної інформації, як результат співвідношення енергетичної i геометричній діяльностей виявлення акустичних сигналів

Приземні шари атмосфери, як і вся повітряне середовище, ніколи не буває безмежною (завжди $\epsilon$ подстилаюча земна поверхня) і однорідною. Розподіл основних фізичних параметрів температури, густини, атмосферного тиску і похідною від них швидкості поширення звуку не буває в реальному середовищі однорідним. Воно або зростає, або зменшується з висотою,

Проблема полягає в тому, що контролювати зміну стану середовища сама по собі досить трудомістке завдання. Тому акустиками було запропоновано сукупність факторів (в тому числі і фактор фокусування), викликаних постійно змінюється в часі $\mathrm{i}$ просторі параметрами середовища відносити до фактору аномалії середовища. Процес визначення аномалії середовища сама по суті $€$ одним з напрямків пізнання навколишнього нас світу, то $\epsilon$ достатньо об'ємною проблемою досліджень. Однак, на практиці вплив фактора аномалії середовища може враховуватися за допомогою коефіцієнта впливу середовища, як окремого випадку.

Отже, енергетична дальність ДЕ виявлення акустичних сигналів з урахуванням фактора аномалії повітряного середовища може визначатися як добуток значення енергетичної дальності виявлення на значення коефіцієнта впливу середовища в приземних шарах атмосфери.

Нехай очікувана дальність виявлення До $є$ результатом твори геометричній дальності Дг на значення коефіцієнта впливу середовища в приземних шарах атмосфери $A$.

У разі нормальної рефракції До $=$ Дг, рис. 8а. Тут акустичні хвилі поширюються прямолінійно, і зона освітленості відділяється від зони тіні лінією (площиною) видимого горизонту. Акустичні хвилі, відбиті від земної поверхні, йдуть вгору.

У разі рівного розподілу геометричної і очікуваної діяльностей виявлення коефіцієнт аномалії $A=1$. Це можливо, коли профіль вертикальний розподіл швидкості поширення звуку залишається постійним. Про це може свідчити вертикальний розподіл температури в приземному шарі атмосфери, яке, як індикатор швидкості звуку, також буде постійним.

У разі негативної рефракції величина швидкості звуку буде плавно спадати 3 висотою. Також плавно з висотою буде спадати і температура. Таке вертикальне розподіл викликає викривлення траєкторій поширення акустичних хвиль (променів) вгору. Вони будуть подібні до дуг великих кіл, як показано на рис. 8 б.

Рефрагируя вгору, акустичні хвилі йдуть вгору, вище лінії видимого горизонту. При цьому зона освітленості значно зменшується, а зона тіні зростає, отже, дальність виявлення зменшується. Нове значення очікуваної дальності дії Д1 буде менше геометричній дальності Дг. Для такого вертикального розподілу значення коефіцієнта $A$ буди рівне $0,8 \div 0,9$.

Коли значення вертикального градієнта зростає, і швидкість зміни з висотою збільшується, рефрагировання (викривлення) акустичних променів також зростає. Наслідком цього $€$ ще більше збільшення зони тіні і зменшення зони освітленості. Виходить, що Д $<$ Д $<$ Дг. Для такого вертикального розподілу коефіцієнт аномалії буде $A=0,7 \div 0,8$.

ще більше зростання вертикального градієнта призведе до більшої рефракції, зменшення очікуваної дальності виявлення до Дз і, відповідно, зменшення коефіцієнта аномалії до $A=0,5 \div 0,7$.

Позитивна рефракція спостерігається в тому випадку, коли швидкість поширення звуку з висотою зростає. Таке їі розподіл призводить до рефракції акустичних хвиль вниз, що дозволяє огинати їм земну 
поверхню (рис. 8, в). Тому очікувана дальність виявлення Д1 зростає в $1,1-1,4$ рази (коефіцієнт $A=1,1 \div 1,4$ ). Зростання вертикальних градієнтів швидкості звуку призводить до зростання очікуваної зонутіні. дальності виявлення Д2 в 1,4 - 1,7 рази і Дз в $1,7-2,0$ рази. Поширення акустичних хвиль за межі лінії видимого горизонту значно розширює зону освітленості і суттєво зменшує
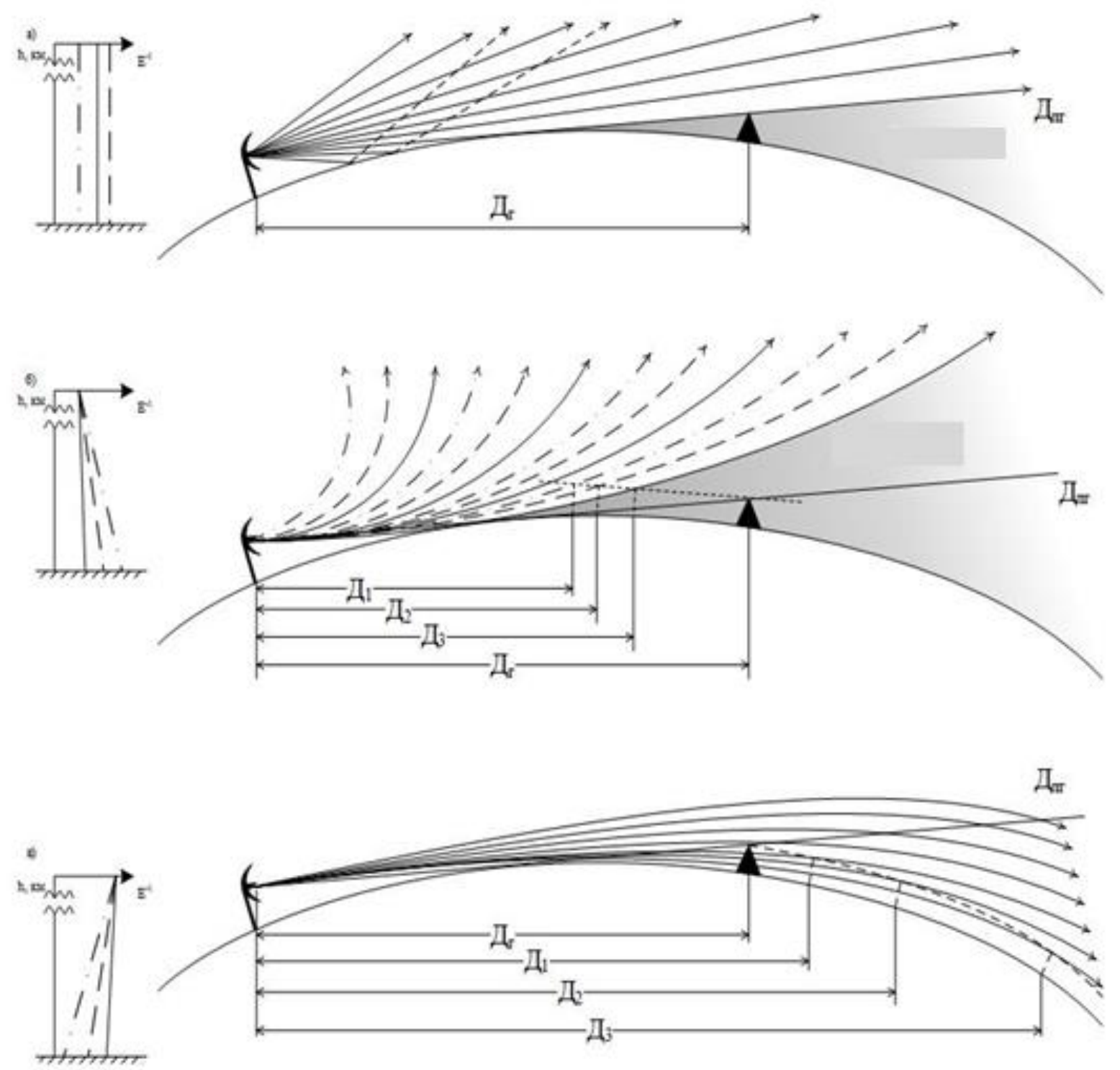

Рисунок 8 - Схема співвідношення діяльностей виявлення. рефракція а) нормальна; б) негативна; в) позитивна

У зонах, де розташовуються великі водні поверхні, такі як затоки, лимани, водосховища, при певних умовах виникають явища надрефракціі, при цьому коефіцієнт аномалії збільшується до 2,5 - 3 і більше, що призводить до зростання очікуваної дальності виявлення в $2-3$ і більше разів.
Значення коефіцієнта аномалії $A$ (коефіцієнта впливу середовища в приземних шарах атмосфери) розраховується аналітично за даними температури, вологості, тиску i сили вітру по емпіричним методикам. Крім цього, існують методики для визначення 
коефіцієнта аномалії по іншим місцевим ознаками.

У ряді випадків для визначення очікуваної дальності виявлення використовують не геометричну, а енергетичну дальність виявлення. Це відбувається в тих випадках, коли ДЕ « Дг. У зв'язку з цим справедливо стверджувати, що:

$$
Д_{0}=A \cdot\left\{\begin{array}{l}
Д_{\Gamma}, \text { якщо Д } Д_{\Gamma} \approx Д_{\mathrm{E}} \\
Д_{\mathrm{E}}, \text { якщо } Д_{\mathrm{E}}<<Д_{\Gamma}
\end{array} .\right.
$$

Необхідно зауважити, що і енергетична, і геометрична, і очікувана дальності виявлення $\epsilon$ результатом аналітичного розрахунку. Дальність виявлення, одержувана в результаті використання спрямованих мікрофонів за прямим призначенням, $\epsilon$ фактичною дальністю виявлення. Вона $\epsilon$ результатом вимірювання дальності тільки що виявленої цілі при певних умовах.

Таким чином, очікувана дальність знімання мовної інформації визначається як добуток енергетичної дальності виявлення акустичних сигналів на значення коефіцієнта впливу середовища в приземних шарах атмосфери. Якщо отриманий результат перевищує значення геометричної дальності виявлення акустичного сигналу, то за значення очікуваної дальності приймається геометрична дальність виявлення.

\section{Висновки}

1. Основними технічними параметрами акустичних засобів знімання мовної інформації $\epsilon$ чутливість мікрофона, його спрямованість, робоча смуга частот і коефіцієнт розпізнавання.

2. Під енергетичною дальністю дії акустичного засобу розуміється найбільше розрахункове значення дистанції, що забезпечує рівність енергетичного потенціалу акустичного засобу та закономірності спаду інтенсивності розповсюджується акустичної хвилі.

3. Геометрична дальність виявлення акустичних сигналів буде визначатися геометричній дальністю видимого горизонту 3 урахуванням позитивного і негативного рельєфу місцевості, наявністю житлових масивів, лісів та водойм, а також станом підстилаючої поверхні навколо об'єкту критичної інфраструктури в напрямку, який визначається розворотом акустичного пристрою.

4. Очікувана дальність знімання мовної інформації визначається як добуток енергетичної дальності виявлення акустичних сигналів на значення коефіцієнта впливу середовища в приземних шарах атмосфери. Якщо отриманий результат перевищує значення геометричної дальності виявлення акустичного сигналу, то за значення очікуваної дальності приймається геометрична дальність виявлення.

\section{Список використаних джерел}

1. Азаренко Е. В. Защита критической инфраструктуры государства от террористического воздействия / Е.В. Азаренко, Ю.Ю. Гончаренко, М.М. Дивизинюк, М.И. Ожиганова // К.: ИГНС HAHУ, 2018. 84 c. (ISBN 978-617-7187-25-6).

2. Азаренко, О., Гончаренко, Ю., Дівізінюк, М., Мірненко, В., \& Сириця, Ю. (2020). Структурно-логічна модель управління надзвичайно ситуацією террористичного характеру та її особливостей, вбудованих скритим електромагнітним впливом на оперативний состав охороняемого об'єкта критичної інфраструктури. Journal of Scientific Papers "Social Development and Security», 10(1), 177-187. DOI: 10.33445/sds.2020.10.1.18

3. Азаров, С., Дівізінюк, М., Лобойченко, В., Мірненко, В., \& Шевченко, Р. (2020). Нові підходи до розробки комплексних методів цивільної безпеки. Journal of Scientific Papers "Social Development and Security", 10(3), 51-63. DOI : 10.33445/sds.2020.10.3.5 4. Про фізичний захист ядерних установок, 


\begin{abstract}
ядерних матеріалів, радіоактивних
відходів, інших джерел іонізуючого випромінювання: Закон України від 19 жовтня 2000 року № 2064-III. URL : http://zakon.rada.gov.ua
\end{abstract}

5. Защита критической инфраструктуры. Концепция основных мер защиты. Рекомендации для предприятий. URL: http://www.bmi.bund.de

6. Инженерные средства физической защиты периметра. URL : http://www.algoritm.org/ arch/arch.php?id=41\&a=734

7. Средства сигнализации в охране стационарных объектов. Интернет публикация. 10.09.2009. - 5 с. URL: http//www.karabiner.ua

8. Xovard B.(1991). Lazeracustic. Optronics. Sincepress. vol. 10. №10. p. 89-100.

9. Видеосъемка и звукозапись - средства, формирующие доказательную базу в ОРД. URL : http://ezop.ua/osnovy-operativ...

10. Гончаренко Ю.Ю., Гончаренко Д. Г., Дівізінюк М. М. Про проблему розрахунку дальності прийому акустичної інформації 3 відкритих майданчиків. Науковотехнічний збірник "Правове, нормативне та метрологічне забезпечення системи захисту інформачії в Україні". - Київ: Державна служба спеціального зв'язку та захисту інформації України НТУУ «КПІ», 2012. - Вип. 1 (23). - С. $29-35$.

11. Азаренко Е.В., Бас О.В., Гончаренко, Ю.Ю.
Дивизинюк М.М., Ожиганова М.И., Рыжкин А.С. Анализ экспериментов по определению дальности съема речевой информации. Науково-технічний збірник «Правове, нормативне та метрологічне забезпечення систем захисту інформачії в Україні». - Київ: Державна служба спеціального звуку та захисту інформації в Україні НТУУ «КПІ», 2019. - Вип. 1 (37). - С. $89-97$.

12. Госсард Е. Волны в атмосфере / Пер. с англ. - М.: Мир, 1978. - 520 с.

13. Гринченко В.Т., Вовк И.В., Маципура В.Т. Основы акустики. - К.: Наукова думка, 2007. -640 c.

14. Гончаренко Ю.Ю. Физическая модель съема речевой информации. Збірник наукових праць «Системи обробки інформації». - Харків: Харківський університет Повітряних Сил імені Івана Кожедуба, 2014. - Вип. 7 (123). - С. 18 - 23.

15. Azarenko , E., Honcharenko , Y., Divizinyuk , M., Mirnenko , V., \& Syrytsia , I. (2020). Structural-logical model of emergency situation management of terrorist character and its features caused by latent electromagnetic influence on the operational staff of the guarded facility of critical infrastructure. Journal of Scientific Papers "Social Development and Security", 10(1), 177-187. DOI : $10.33445 /$ sds.2020.10.1.18

\section{Влияние технических и географических параметров на дальность съемки речевой информации при решении прикладных задач}

\footnotetext{
Елена Азаренко * 1 А; Юлия Гончаренко 2 в; Михаил Дивизинюк ${ }^{3}$; Владимир Мирненко ${ }^{4 \mathrm{D}}$; Валерий Стрелец ${ }^{5 \mathrm{~A}}$

* Corresponding author: ${ }^{1}$ д.ф-м.н., профессор, заместитель руководителя, e-mail: azarenko_ev@ukr.net, ORCID: 0000-0003-2927-5545

2 к.т.н., доцент, профессор кафедры, e-mail: vup@e-u.in.ua, ORCID: 0000-0003-2045-0263

3 д.ф-м., профессор, главный научный сотрудник, e-mail: divizinyuk@ukr.net, ORCID: 0000-0002-5657-2302

${ }^{4}$ д.т.н., профессор, директор департамента, e-mail: mirnenkovi@gmail.com, ORCID: 0000-0002-7484-1035 ${ }^{5}$ руководитель, e-mail: v.strelec.brand@gmail.com, ORCID: 0000-0003-1913-7878

А Научно-исследовательский лабораторно-экспериментальный центр “БРАНД ТРЕЙД”, Киев, Украина. в Европейский университет, г. Киев, Украина.

с Институт геохимии и окружающей среды НАН Украины, Киев, Украина.

D Департамент военного образования и науки Министерства обороны Украины, г. Киев, Украина.
} 


\begin{abstract}
Аннотация
Статья посвящена рассмотрению основных технических параметров акустических средств и географических факторов местности на дальность съема речевой информации при решении прикладных задач защиты объектов критической инфраструктуры от террористических актов. Первоначально дана характеристика основных технических параметров акустических средств съемки речевой информации. Показано, что основными техническими параметрами акустических средств съема речевой информации являются чувствительность микрофона, его направленность, рабочая полоса частот и коэффициент распознавания. Затем рассмотреть понятие энергетической дальности обнаружения акустических сигналов. Показано, что под энергетической дальностью действия акустического средства понимается наибольшее расчетное значение дистанции, что обеспечивает равенство энергетического потенциала акустического средства $и$ закономерности спада интенсивности распространяющейся акустической волны. После чего проанализирована геометрическая дальность обнаружения акустических сигналов с учетом рельефа местности вокруг объекта критической инфраструктуры. Показано, что геометрическая дальность обнаружения акустических сигналов будет определяться геометрической дальностью видимого горизонта с учетом положительного и отрицательного рельефа местности, наличием жилых массивов, лесов и водоемов, а также состоянием подстилающей поверхности вокруг объекта критической инфраструктуры в направлении, определяемом разворотом акустического устройства. Затем рассмотрена ожидаемая дальность съема речевой информации, как результат соотношения энергетической и геометрической деятельности обнаружения акустических сигналов. Показано, что ожидаемая дальность съема речевой информации определяется как произведение энергетической дальности обнаружения акустических сигналов на значение коэффициента воздействия среды в приземных слоях атмосферы. Если полученный результат превышает значение геометрической дальности обнаружения акустического сигнала, то при значении ожидаемой дальности принимается геометрическая дальность обнаружения.
\end{abstract}

Ключевые слова: террористический акт, защита, акустический контроль, микрофон, дальность.

\title{
Influence of technical and geographical parameters on the range of language information retrieval in solving applied problems
}

\author{
Olena Azarenko * 1A; Yulia Honcharenko 2B; Mykhailo Divizinyuk ${ }^{3 \mathrm{C}}$; \\ Volodymyr Mirnenko ${ }^{4}$; ; Valeriy Strilets ${ }^{5 \mathrm{~A}}$ \\ * Corresponding author: ${ }^{1}$ Dr, Professor, Deputy Head, e-mail: e-mail: azarenko_ev@ukr.net, ORCID: 0000-0003-2927-5545 \\ ${ }^{2}$ Ph.D., Associate Professor, Professor of Department, e-mail: vup@e-u.in.ua, ORCID: 0000-0003-2045-0263 \\ ${ }^{3}$ Dr, Professor, Head of Department, e-mail: divizinyuk@ukr.net, ORCID: 0000-0002-5657-2302 \\ ${ }^{4}$ Dr, Professor, Director of the Department, e-mail: mirnenkovi@gmail.com, ORCID: 0000-0002-7484-1035 \\ ${ }^{5}$ Head, e-mail: v.strelec.brand@gmail.com, ORCID: 0000-0003-1913-7878 \\ A Research laboratory-experimental center "BRAND TRADE", Kyiv, Ukraine \\ ${ }^{B}$ European University, Kyiv, Ukraine \\ c Institute of Environmental Geochemistry of the NAS of Ukraine, Kyiv, Ukraine \\ ${ }^{D}$ Department of Military Education and Science of the Ministry of Defense of Ukraine, Kyiv, Ukraine
}

\begin{abstract}
This article is devoted to the consideration of the main technical parameters of acoustic means and geographical factors of the area on the range of language information in the solution of applied problems of protection of critical infrastructure from terrorist acts. First, the characteristics of the main technical parameters of acoustic means of recording speech information are given. It is shown
\end{abstract}


that the main technical parameters of acoustic means of recording speech information are the sensitivity of the microphone, its direction, the operating frequency band and the recognition factor. Then consider the concept of energy range detection of acoustic signals. It is shown that the energy range of the acoustic means is the largest calculated value of the distance, which ensures the equality of the energy potential of the acoustic and the regularity of the decrease in the intensity of the propagating acoustic wave. Then the geometric range of detection of acoustic signals was analyzed, taking into account the terrain around the critical infrastructure object. It is shown that the geometric range of acoustic signals will be determined by the geometric distance of the visible horizon, taking into account the positive and negative terrain, the presence of housing, forests and water, and the state of the underlying surface around the critical infrastructure in the direction determined by the acoustic device. Then the expected range of speech information is considered as a result of the ratio of energy and geometric activities for the detection of acoustic signals. It is shown that the expected range of speech information is defined as the product of the energy range of detection of acoustic signals on the value of the coefficient of influence of the environment in the surface layers of the atmosphere. If the obtained result exceeds the value of the geometric detection range of the acoustic signal, the value of the expected range is the geometric detection range.

Keywords: terrorist act, protection, acoustic control, microphone, range.

\section{References}

1. Azarenko E. V., Goncharenko, Yu. Yu., Divizinyuk, M. M., Ozhiganova, M. I. Protection of the critical infrastructure of the state from terrorist influence. Kyiv: IGNS NASU, 2018.84 p. (ISBN 978-617-7187-25-6). [in Ukrainian]

2. Azarenko, E., Honcharenko, Y., Divizinyuk, M., Mirnenko, V., \& Syrytsia, I. (2020). Structurallogical model of emergency situation management of terrorist character and its features caused by latent electromagnetic influence on the operational staff of the guarded facility of critical infrastructure. Journal of Scientific Papers "Social Development and Security», 10(1), 177-187. DOI : 10.33445/sds.2020.10.1.18

3. Azarov, S., Divizinyuk, M., Loboichenko , V., Mirnenko , V., \& Shevchenko, R. (2020). New approaches to the development of integrated methods of civil security. Journal of Scientific Papers "Social Development and Security», 10(3), 51-63. DOI : 10.33445/sds.2020.10.3.5

4. About the physical seizure of nuclear installations, nuclear materials, radioactive sources, and other dangers of ionizing vypromynuvannya: Law of Ukraine dated 19 June 2000 roku No. 2064-III. Available from : <http://zakon.rada.gov.ua> [in Ukrainian]
5. Protecting critical infrastructure. Concept of basic protection measures. Recommendations for enterprises. Available from : <http://www.bmi.bund.de>

6. Engineering means of physical protection of the perimeter. Available from: $<$ http://www.algoritm.org/arch/arch.php?id $=41 \& a=734>$

7. Signaling means in the protection of stationary objects. Internet publication. 09/10/2009. 5 p. Available from : $<$ http//www.karabiner.ua>

8. Xovard B. (1991). Lazeracustic. Optronics. Sincepress. vol. 10. №10. p. 89-100.

9. Video filming and sound recording are the means that form the evidence base in the ORD. Available from : <http://ezop.ua/osnovy-operativ>

10. Goncharenko, Yu.Yu., Goncharenko, D.G., Divizinyuk, M.M. Science and Technology Zbirnik "Legal, normative and metrological safety of the information system in Ukraine". Kyiv: State Service for Special Call to the Information Officer of Ukraine NTUU "KPI", 2012. VIP. 1 (23). P. 29-35. [in Ukrainian]

11. Azarenko, E.V., Bas, O.V., Goncharenko, Yu.Yu. Divizinyuk, M.M., Ozhiganova, M.I., Ryzhkin, A.S. Analysis of experiments to determine the range of voice information 
retrieval. Science and technology collection "Legal, normative and metrological safety of systems for information retrieval in Ukraine". Kyiv: State Service for Special Sound and Information in Ukraine NTUU "KPI", 2019.VIP. 1 (37). P. 89-97. [in Ukrainian]

12. Gossard E. Waves in the atmosphere / Per. from English. Moscow.: Mir, 1978. 520 p. [in Russian]

13. Grinchenko, V.T., Vovk, I.V., Matcipura, V.T. Basics of acoustics. Kyiv: Naukova Dumka, 2007. 640 p. [in Ukrainian]

14. Goncharenko, Yu.Yu. (2014). Physical model of speech information collection. Collection of scientific works "Information processing systems". Kharkiv: Ivan Kozhedub Kharkiv University of the Air Force, Vol. 7 (123). Pp. 18-23. [in Ukrainian]

15. Azarenko, E., Honcharenko , Y., Divizinyuk, M., Mirnenko , V., \& Syrytsia , I. (2020). Structural-logical model of emergency situation management of terrorist character and its features caused by latent electromagnetic influence on the operational staff of the guarded facility of critical infrastructure. Journal of Scientific Papers "Social Development and Security», 10(1), 177-187. DOI : 10.33445/sds.2020.10.1.18 